\title{
Does sex influence the impact that smoking, treatment interruption and impaired pulmonary function have on outcomes in limited stage small cell lung cancer treatment?
}

\author{
Gregory MM Videtic $M D^{1}$, Pauline T Truong $M D^{2}$, Robert B Ash $M D^{3}$, Edward W Yu MD ${ }^{3}$, Walter I Kocha $M D^{4}$, \\ Mark D Vincent $\mathrm{MD}^{4}$, Anna T Tomiak MD ${ }^{5}$, A Rashid Dar MD³, Frances Whiston MSc ${ }^{6}$, Larry W Stitt MSc ${ }^{6}$
}

\begin{abstract}
GMM Videtic, PT Truong, RB Ash, et al. Does sex influence the impact that smoking, treatment interruption and impaired pulmonary function have on outcomes in limited stage small cell lung cancer treatment? Can Respir J 2005;12(5):245-250.
\end{abstract}

PURPOSE: To look for survival differences between men and women with limited stage small cell lung cancer (LS-SCLC) by examining stratified variables that impair treatment efficacy.

METHODS: A retrospective review of 215 LS-SCLC patients treated from 1989 to 1999 with concurrent chemotherapy-radiotherapy modelled on the 'early-start' thoracic radiotherapy arm of a National Cancer Institute of Canada randomized trial.

RESULTS: Of 215 LS-SCLC patients, 126 (58.6\%) were men and $89(41.4 \%)$ were women. Smoking status during treatment for 186 patients (86.5\%) was: 107 (58\%) nonsmoking (NS) (76 [71\%] male [M]; 31 [29\%] female [F]) and 79 (42\%) smoking (S) (36 M [46\%]; 43 F [54\%]) (continuing-to-smoke $\mathrm{F}$ versus $\mathrm{M}, \mathrm{P}=0.001$ ). Fifty-six patients (26\%) had radiotherapy interruptions (RTI) during chemotherapy-radiotherapy because of toxicity. Radiotherapy breaks were not associated with sex $(\mathrm{P}=0.95)$. Survival by sex and smoking status at two years was: $\mathrm{F}+\mathrm{NS}=38.7 \% ; \mathrm{F}+\mathrm{S}=21.6 \% ; \mathrm{M}+\mathrm{NS}=22.9 \%$; and $\mathrm{M}+\mathrm{S}=9.1 \%(\mathrm{P}=0.0046)$. Survival by sex and RTI status at two years was: $\mathrm{F}+$ no $\mathrm{RTI}=32.4 \% ; \mathrm{F}+\mathrm{RTI}=23.6 \% ; \mathrm{M}+$ no $\mathrm{RTI}=23.0 \%$; and $\mathrm{M}+\mathrm{RTI}=3.8 \%(\mathrm{P}=0.0025)$. Diffusion capacity for carbon monoxide (DLCO) was recorded for 86 patients $(40 \%)$ and median survival by sex and DLCO was $\mathrm{F}=16.7$ months and $\mathrm{M}=12.1$ months for a DLCO less than $60 \%$; and for a DLCO $60 \%$ or more, $\mathrm{F}=15.1$ months and $\mathrm{M}=15.3$ months. First relapses were recorded in 132 cases $(61 \%)$, with chest failure in men $(45 \%)$ greater than for women $(35 \%)$ and cranial failure rates similar between sexes (48\%). Upon multivariable analysis, continued smoking was the strongest negative factor affecting survival.

CONCLUSIONS: In LS-SCLC, women overall do better than men, with or without a negative variable. The largest quantifiable improvement in survival for women came from smoking cessation, and for men from avoidance of breaks during treatment.

Key Words: Chemoradiotherapy; Limited stage; Prognosis; Sex; Small cell lung cancer

\section{Le sexe influence-t-il les répercussions du tabagisme, de l'interruption du traitement et d'une insuffisance pulmonaire sur les issues du traitement du cancer du poumon localisé à petites cellules?}

\begin{abstract}
BUT : Rechercher les différences de survie entre les hommes et les femmes atteints de cancer du poumon localisé à petites cellules (CPLPC) en examinant des variables stratifiées qui nuisent à l'efficacité du traitement. MÉTHODOLOGIE : Analyse rétrospective de 215 patients atteints d'un CPLPC traités entre 1989 et 1999 par chimiothérapie-radiothérapie concomitante modelée sur la branche de radiothérapie thoracique " à début précoce " d'un essai aléatoire de l'Institut national du cancer du Canada.
\end{abstract} RÉSULTATS : Des 215 patients atteints d'un CPLPC, 126 (58,6 \%) étaient des hommes, et 89 (41,4\%), des femmes. Le tabagisme pendant le traitement de 186 patients (86,5\%) s'établissait comme suit : 107 (58\%) non-fumeurs (NF) (76 [71 \%] hommes [H], 31 [29\%] femmes [F]) et 79 (42\%) fumeurs (FU) (36 H [46 \%], 43 F [54 \%]) (F continuant à fumer par rapport aux $\mathrm{H}, \mathrm{P}=0,001)$. Cinquante-six patients (26\%) ont subi des interruptions de la radiothérapie (IRT) pendant la chimiothérapieradiothérapie pour des raisons de toxicité. Ces pauses n'étaient pas associées au sexe $(\mathrm{P}=0,95)$. La survie selon le sexe et le tabagisme au bout de deux ans correspondait à ce qui suit : $\mathrm{F}+\mathrm{NF}=38,7 \%, \mathrm{~F}+\mathrm{FU}=21,6 \%$, $\mathrm{H}+\mathrm{NF}=22,9 \%, \mathrm{H}+\mathrm{FU}=9,1 \%(\mathrm{P}=0,0046)$. La survie selon le sexe et l'IRT au bout de deux ans équivalait à ce qui suit : $\mathrm{F}+$ sans $\mathrm{IRT}=32,4 \%$, $\mathrm{F}+\mathrm{IRT}=23,6 \%, \mathrm{H}+$ sans $I R T=23,0 \%, \mathrm{H}+\mathrm{IRT}=3,8 \%(\mathrm{P}=0,0025) . \mathrm{La}$ capacité de diffusion pulmonaire du monoxyde de carbone (CDPMC) était indiquée à l'égard de 86 patients (40\%), et la survie médiane selon le sexe et la CDPMC inférieure à $60 \%$ s'établissait comme suit : $F=16,7$ mois et $\mathrm{H}=12,1$ mois. Lorsque la CDPMC était de $60 \%$ ou plus, $\mathrm{F}=15,1$ mois et $\mathrm{H}=15,3$ mois. Une première rechute a été enregistrée dans 132 cas (61\%), l'insuffisance thoracique chez les H (45\%) étant plus élevée que chez les $\mathrm{F}(35 \%)$ et les taux d'insuffisance crânienne étant similaires entre les sexes (48\%). Selon l'analyse multivariable, le fait de continuer à fumer constituait le principal facteur négatif nuisant à la survie.

CONCLUSIONS : En cas de CPLPC, l'ensemble des femmes s'en sort mieux que les hommes, avec ou sans variable négative. La principale amélioration quantifiable de survie pour les femmes était attribuable au renoncement au tabac, et pour les hommes, au fait d'éviter d'interrompre le traitement.

${ }^{1}$ Department of Radiation Oncology, Cleveland Clinic Foundation, Cleveland, Ohio, USA; ${ }^{2}$ Department of Radiation Oncology, British Columbia Cancer Agency - Vancouver Island Cancer Centre, Victoria, British Columbia; Departments of ${ }^{3}$ Radiation Oncology, ${ }^{4}$ Medical Oncology and ${ }^{6}$ Biometry, London Regional Cancer Centre, University of Western Ontario, London; ${ }^{5}$ Department of Medical Oncology, Kingston Regional Cancer Centre, Kingston, Ontario

Correspondence: Dr Gregory MM Videtic, Department of Radiation Oncology/T28, Cleveland Clinic Foundation, 9500 Euclid Avenue,

Cleveland, Ohio 44195, USA. Telephone 216-444-9797, fax 216-445-1068, e-mail videtig@ccf.org 
$T^{\mathrm{h} e}$ he contemporary management of limited stage small cell lung cancer (LS-SCLC) includes chemotherapy (ChT), thoracic radiotherapy (RT) and prophylactic cranial irradiation (PCI) $(1,2)$. The administration of RT concurrent with the first cycle of platinum-based ChT is the current standardof-care and is based on a number of randomized clinical trials that demonstrate improved survival for 'early' versus 'late' RT (3-6). Nevertheless, because survival rates are modest at best, optimal drug combinations and total RT dose and scheduling remain areas of active investigation.

A range of clinical, laboratory, tumour and host factors have been found to influence the survival achievable in SCLC (7). Our group has published three recent studies (8-10), suggesting that interruptions in patients' therapy, due to treatment toxicity, compromised pretreatment pulmonary function (PFT) status, and patient smoking behaviour during treatment negatively influences outcomes. Specifically, RT interruptions used to palliate ChT/RT toxicity are associated with decreased survival and local control (8). Continued tobacco use during ChT/RT also decreases survival (9), and impaired diffusion capacity for carbon monoxide (DLCO) is associated with increased toxicity from concurrent ChT/RT and decreased survival (10). An incidental finding in these studies, revealed on multivariable analysis, was that despite the negative variables, female sex emerged as a strong positive prognostic factor (8-10). In itself, this fit with a large number of previous reports demonstrating female sex to be a positive factor in SCLC (11-15), as compared with a smaller number of reports that show sex has no effect on survival $(16,17)$.

Because our previous studies were not designed to quantify how survival changes for each sex (if one stratifies by factors that negatively influence treatment efficacy), we carried out an analysis to measure the interaction between patient sex and the combined influence on survival in LS-SCLC of smoking habits during treatment, PFT and the rate of RT interruptions due to toxicity. We carried out this retrospective review using our single institution database consisting of patients treated over a 10-year period using a ChT/RT regimen modelled after the 'early RT start' arm of the randomized National Cancer Institute of Canada trial reported by Murray et al (3). For the LS-SCLC patient offered curative management, determining how differing variables interact to influence outcome is of interest to both patient and physician alike because, in contrast to a fixed variable like sex, factors impairing treatment may have the potential to be modified to optimize results.

\section{METHODS}

A retrospective chart review of all SCLC patients seen at the London Regional Cancer Centre, London, Ontario, between January 1989 and October 1999 revealed 215 patients treated for a diagnosis of LS-SCLC. The institutional management policy for LS-SCLC was modelled after the 'early' RT arm of the National Cancer Institute of Canada randomized trial $(3,18)$, in which RT was initiated with the second of a six-cycle ChT program. No patients in the present analysis were treated on other protocols or trials.

All patients had a pathologically confirmed diagnosis of SCLC. Pretreatment staging consistently included complete blood count, screening blood chemistry, chest radiograph, computed tomography (CT) of the thorax and upper abdomen, and bone scan. Patient fitness was scored using Karnofsky Perfomance Status (KPS) criteria. In the present study, all patients had a smoking history and their smoking status was recorded at the initiation of the treatment regimen. Ultrasound of the abdomen, bone marrow biopsy and CT of the brain were performed when dictated by clinical findings. Due to variations in clinicians' definition of LS-SCLC at presentation, 13 patients (7\%) had contralateral supraclavicular nodes and four patients $(1.9 \%)$ had a malignant pleural effusion. Pretreatment (prebronchodilator) pulmonary function values recorded for this patient population included forced expiratory volume in $1 \mathrm{~s}$ (L, per cent predicted) and DLCO as per cent predicted (19). For the present study, the measure of interest was the DLCO because a previous study had demonstrated its significant association with poorer outcomes (10).

\section{ChT}

ChT consisted of a six-cycle regimen of cyclophosphamide $\left(1000 \mathrm{mg} / \mathrm{m}^{2}\right)$, doxorubicin $\left(50 \mathrm{mg} / \mathrm{m}^{2}\right)$ or epirubicin $\left(50 \mathrm{mg} / \mathrm{m}^{2}\right)$, vincristine ( $2 \mathrm{mg}$ total dose) (CAV; CEV) alternating at threeweek intervals with both etoposide $\left(100 \mathrm{mg} / \mathrm{m}^{2}\right)$ and cisplatin $\left(25 \mathrm{mg} / \mathrm{m}^{2}\right)(\mathrm{EP})$ given on three consecutive days. All agents were administered by intravenous injections or infusion. Drug dosage adjustments were made according to treatment day neutrophil count and serum creatinine. Drug schedules evolved over the 10 -year interval such that $82 \%$ of patients received alternating $\mathrm{CAV}$, or $\mathrm{CEV}+\mathrm{EP}$, and $18 \%$ received six cycles of EP alone.

\section{RT}

Two RT prescriptions were employed over the study period. In the early 1990s, RT consisted of 40 Gy in 15 fractions over three weeks as per Murray et al's trial design (3). In the late 1990s, following an internal institutional review, total RT dose was modified to $50 \mathrm{~Gy}$ in 25 fractions over five weeks. (This modification was made to reflect 'conventional' RT prescribing, ie, a daily fraction dose of 1.8 Gy to 2 Gy) (20). Target definitions were similar for both dose prescriptions. RT was administered with the second or third cycle of ChT for $85 \%$ of patients (the remainder starting RT with cycles 4 to 6) and always concurrent with EP only.

PCI, consisting of 25 Gy in 10 fractions over two weeks, was administered following ChT/RT and after full restaging with CT imaging of the head, chest and abdomen, as well as a bone scan. PCI was offered only to complete responders according to individual clinician preference.

\section{Treatment interruptions}

Hematological criteria for interruptions during concurrent ChT/RT included an absolute neutrophil count of $1000 / \mu \mathrm{L}$ or less; neutropenic fever or sepsis, and a platelet count of $80,000 / \mu \mathrm{L}$ or less. Locoregional symptomatology included severe esophagitis (ie, severe odynophagia/dysphagia, intolerable pain), impaired nutrition with nausea/vomiting, and dehydration requiring hospitalization. For the purpose of the present study, the marker for any toxicity-related treatment break was the length of any interruption in the RT schedule during the concurrent phase of LS-SCLC treatment.

\section{Follow-up}

Follow-up evaluations were performed every three months as per the model of Murray et al (3). Patient mortality data were collected from death registries and family contacts.

\section{Analysis}

Overall survival was defined as the interval between the date of pathological diagnosis and death, or the last follow-up with any 
TABLE 1

Comparison of selected patient and treatment characteristics according to sex

\begin{tabular}{|c|c|c|c|c|c|}
\hline & \multicolumn{2}{|c|}{ Male $(n=126)$} & \multicolumn{2}{|c|}{ Female $(n=89)$} & \multirow[b]{2}{*}{$\mathbf{P}$} \\
\hline & & $\%$ & & $\%$ & \\
\hline Mean age at diagnosis (years) & 63.7 & - & 62.2 & - & 0.37 \\
\hline Age $\geq 60$ & 86 & 68.3 & 60 & 67.4 & 0.90 \\
\hline Karnofsky Performance Status $\geq 80$ & 68 & 54.0 & 48 & 53.9 & 0.99 \\
\hline \multicolumn{6}{|l|}{ Supraclavicular nodes } \\
\hline Ipsilateral & 13 & 10.3 & 13 & 14.6 & 0.34 \\
\hline Contralateral & 9 & 7.1 & 4 & 4.5 & 0.42 \\
\hline \multicolumn{6}{|l|}{ Diffusion capacity of carbon monoxide } \\
\hline$\geq 60 \%$ & 33 & 62.0 & 21 & 64.0 & \multirow[t]{2}{*}{0.90} \\
\hline$<60 \%$ & 20 & 38.0 & 12 & 36.0 & \\
\hline Median number of pack-years smoking (range) & $50(2$ to 250$)$ & - & $40(13$ to 106$)$ & - & NS \\
\hline $\begin{array}{l}\text { Median number of months pretreatment } \\
\text { smoking cessation (range) }\end{array}$ & $4(1$ to 240$)$ & - & $5(1$ to 156$)$ & - & NS \\
\hline \multicolumn{6}{|l|}{ Smoking on treatment } \\
\hline Yes & 36 & 46.0 & 43 & 54.0 & \multirow[t]{2}{*}{0.0005} \\
\hline No & 76 & 71.0 & 31 & 31.0 & \\
\hline Prophylactic cranial irradiation received & 25 & 20.0 & 23 & 25.8 & 0.31 \\
\hline \multicolumn{6}{|l|}{ Radiotherapy dose } \\
\hline $40 \mathrm{~Gy} / 15$ fractions over three weeks & 63 & 50.0 & 59 & 66.0 & \multirow[t]{2}{*}{0.03} \\
\hline 50 Gy/25 fractions over five weeks & 62 & 50.0 & 30 & 34.0 & \\
\hline Treatment toxicities & 43 & 38.4 & 29 & 36.7 & 0.81 \\
\hline Treatment interruptions & 33 & 26.2 & 23 & 25.8 & 0.95 \\
\hline
\end{tabular}

death defined as an event. Survival estimates (log-rank) were obtained using Kaplan-Meier methodology. The interaction test was two-tailed and $\mathrm{P}<0.05$ was considered to be statistically significant. Cox multivariable analysis using a forced entry model was used to test the impact multiple variables had on overall survival.

\section{RESULTS}

Median follow-up was 14.8 months (range 2.3 to 84.5 months). At the time of analysis, 23 patients $(10.7 \%)$ were alive and $192(89.3 \%)$ were dead. For the entire study cohort, actuarial overall survival was $22.7 \%$ at two years and $7.2 \%$ at five years, with a median survival of 14.7 months.

Among the 215 LS-SCLC patients, there were 126 men $(58.6 \%)$ and 89 women $(41.4 \%)$. Median age at diagnosis was 63 years (range 32 to 94 years). Median KPS of the group was 80 (range 60 to 90). The administered thoracic RT dose was $40 \mathrm{~Gy}$ in 15 fractions over three weeks in 122 cases (57\%) and 50 Gy in 25 fractions over five weeks for 92 patients (43\%). RT information was unavailable in one case and DLCO values were recorded for 86 patients $(40 \%)$.

Smoking status before treatment was recorded in 186 patients $(86.5 \%)$ and data were incomplete in 29 patients $(13.5 \%)$. The median number of pack-years smoked was 45 (range two to 250 pack-years). Of the 186 analyzable patients, 79 (42\%) continued to smoke during treatment and 107 (58\%) stopped before treatment. The median duration of smoking cessation before treatment was 4.5 months (range one to 240 months).

A total of 56 patients (26\%) required treatment interruptions during concurrent ChT/RT for hematological and/or locoregional toxicities. Reasons documented included myelosuppression $(88 \%)$ (neutropenia alone, with sepsis, or with thrombocytopenia [86\%]; thrombocytopenia alone [1.8\%]); esophagitis (12.5\%); and nausea and vomiting, dehydration or other $(10.7 \%)$. The median duration of a treatment 'break' was five days (range one to 18 days).

Table 1 presents data comparing pretreatment patient variables by sex cohort. There was a higher proportion of women among those who continued to smoke while on therapy $(\mathrm{P}=0.0005)$. Two-thirds of the women received an RT dose of 40 Gy/15 fractions, with the remaining one-third receiving $50 \mathrm{~Gy} / 25$ fractions $(\mathrm{P}=0.03)$.

Figure 1 provides a comparison of overall survival for LS-SCLC patients treated with $\mathrm{ChT} / \mathrm{RT}$ as a function of sex. The fiveyear overall survival of women $(12.5 \%)$ was fivefold greater than that of men $(2.5 \%)(\mathrm{P}=0.07)$. Figures 2 and 3 demonstrate the interaction between sex and smoking status during treatment; and the use of treatment interruptions, respectively, with the resulting impact on overall survival. Female nonsmokers had the best overall survival compared with female smokers and men smoking or not $(\mathrm{P}=0.0046)$. Women without treatment breaks survived longer than men, and patients of either sex with breaks $(\mathrm{P}=0.0025)$. Table 2 provides the median survival, two- and five-year survival rates according to sex, smoking status and treatment breaks. For each sex, the absence of smoking during treatment or avoidance of interruptions in therapy resulted in improved survival. For absolute survival improvements at two years for nonsmokers, women improved by $17.1 \%$ and men by $13.8 \%$; for treatment breaks, women by $8.8 \%$ and men by $19.2 \%$. When comparisons were made between sexes, survival rates of men were always inferior to that of women, irrespective of treatment factor status. Also, survival of men without a given variable never surpassed women with that factor.

With respect to DLCO, there were 32 patients with values less than $60 \%$ and 54 patients with values of $60 \%$ or more. Figure 4 is a plot of survival as a function of DLCO status and sex. Although not significant in this analysis, likely due to 


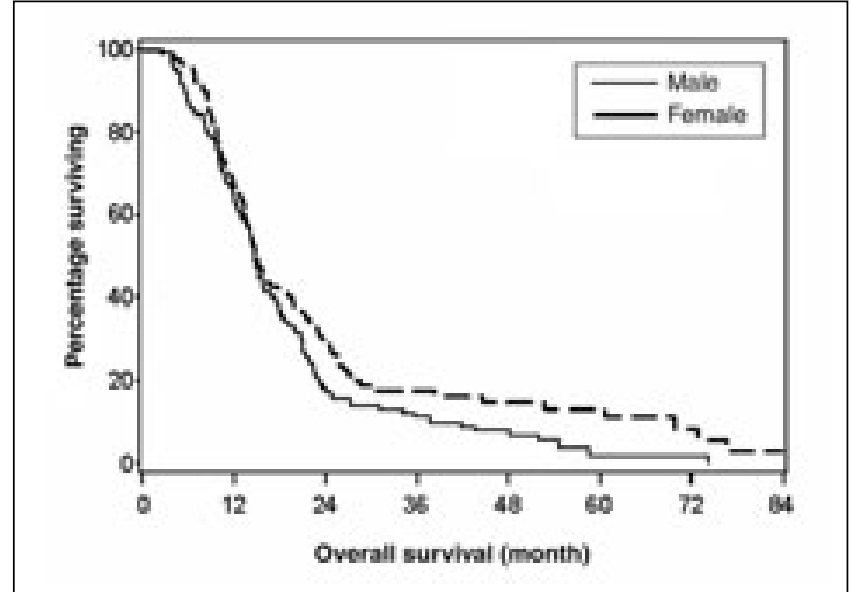

Figure 1) The impact of sex on overall survival in limited stage small cell lung cancer $(P=0.07)$

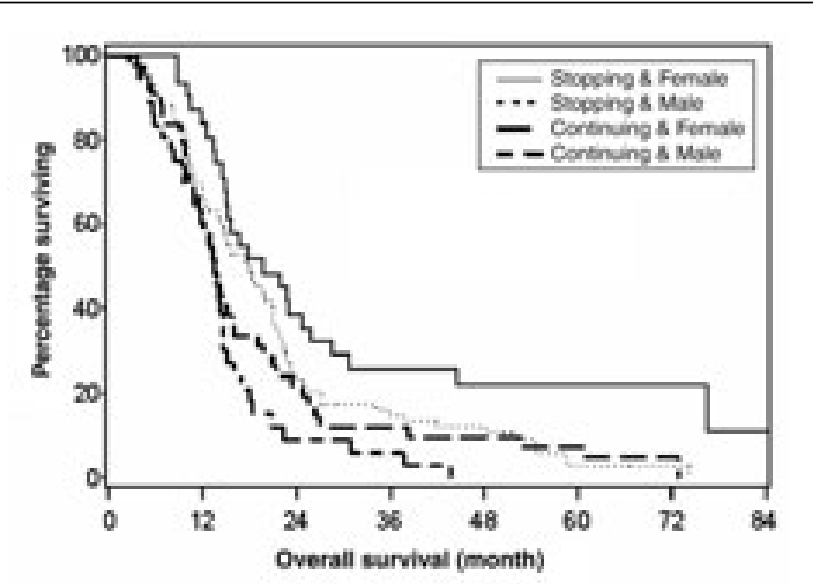

Figure 2) The impact of sex and smoking status during treatment on overall survival in limited stage small cell lung cancer (log rank $P=0.0046$ )

small patient numbers, median survival for women and men with DLCO less than $60 \%$ was 16.7 and 12.1 months, respectively, and for $60 \%$ or greater, 15.1 and 15.3 months, respectively. Thus, men had an absolute median survival improvement of 3.2 months with improvements in DLCO.

Sites of first relapse were recorded for 132 patients $(61 \%)$ at the time of analysis. Thoracic failure was recorded more frequently among men than women ( $45 \%$ versus $35 \%$, respectively) but the small patient numbers did not render this difference statistically significant. The incidence of first relapse in the brain was similar for both sexes (48\%). The most significant factor negatively influencing overall survival on multivariable analysis of selected prognostic factors, including

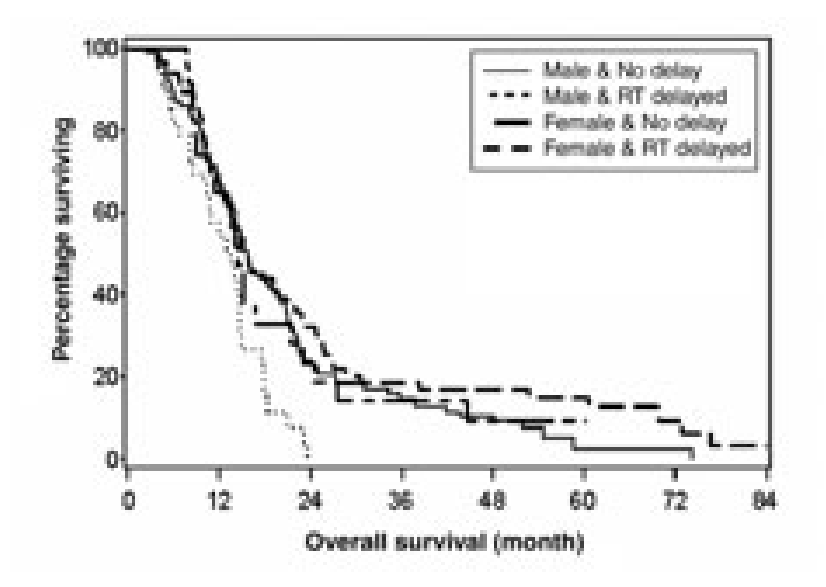

Figure 3) The impact of sex and treatment interruptions ('delays') on overall survival in limited stage small cell lung cancer (log rank $P=0.0025)$. RT Radiotherapy

age, KPS, continued smoking, sex, treatment delay and DLCO was continued smoking (hazard ratio $2.41 ; 95 \%$ CI 1.3 to 4.5 ; $\mathrm{P}=0.0056$ ).

\section{DISCUSSION}

The goal of the present retrospective study was to 'quantify' the interaction of patient sex with potentially alterable variables known to affect the efficacy of concurrent ChT/RT used to treat LS-SCLC. The results suggest, firstly, that women tend to do better than men, irrespective of the particular variable under study. This strong positive prognostic association between female sex and survival is supported by the majority of published reports on the impact of sex on a diagnosis of LS-SCLC (11-15). In our study, we found an overall fivefold absolute difference in survival at five years favouring women over men. Secondly, for both men and women, there was a significant benefit to smoking cessation and completing treatments as prescribed, with incremental improvements in survival of approximately $10 \%$ to $20 \%$. For women, the greatest decrement to survival came from smoking and, for men, from treatment interruptions. Less significant was the impact of changes in DLCO above and below the cutoff of $60 \%$ predicted, with the suggestion of an improved median survival of three months for men only. Our results suggest that although the greatest benefits with respect to outcome in LS-SCLC are a function of a nonmodifiable variable (ie, patient sex), there is nonetheless the possibility to optimize for each sex by correcting for specific behaviours known to impair treatment efficacy.

The effect of sex on LS-SCLC outcomes in the present study could not be attributed to important imbalances between the sexes over a range of variables tested. In the report by Videtic et al (21), looking at the impact of the two

TABLE 2

Comparison of overall survival rates according to sex and treatment variables

\begin{tabular}{|c|c|c|c|c|c|c|c|c|}
\hline & \multicolumn{4}{|c|}{ Female } & \multicolumn{4}{|c|}{ Male } \\
\hline & No delay* & Delay* & Nonsmoking & Smoking & No Delay* & Delay* & Nonsmoking & Smoking \\
\hline $\mathrm{n}$ & 66 & 23 & 31 & 43 & 93 & 33 & 76 & 36 \\
\hline Two-year (\%) & 32.4 & 23.6 & 38.7 & 21.6 & 23.0 & 3.8 & 22.9 & 9.1 \\
\hline Five-year (\%) & 12.7 & Censored & 22.1 & 7.2 & 2.6 & 0 & 3.0 & 0 \\
\hline
\end{tabular}

${ }^{*}$ Radiotherapy interruption 
RT prescriptions on outcomes, no significant differences were found between the two dose schedules with respect to overall survival, toxicity or local control. Similarly, in the studies on treatment interruptions (8), impaired pulmonary function (10) and their respective impact on survival and toxicity, there were no significant differences to account for varying outcomes between the cohorts as a function of age, sex, performance status or any other patient-, tumour- or treatment-related variable.

A number of mechanisms have been proposed to explain the altered survivals seen with adverse treatment factors. In the study looking at the impact of treatment interruptions on LS-SCLC outcomes, the poorer survival and decreased local control seen in patients with breaks was judged to reflect the selection of resistant cell clones through repopulation mechanisms triggered by the RT interruption (8). To explain why patients who continued to smoke during treatment had poorer survival, we found evidence that components of cigarette smoke enhance intrinsic cell virulence leading to more effective metastasis and/or resistance, whereas other compounds directly interfere with the cytotoxic actions of ChT and RT (9). With respect to DLCO and outcomes, we hypothesized that DLCO acts as a marker (like KPS) of global patient fitness reflected in treatment tolerance and influencing survival through evolving delayed toxicity at the level of the lung (10).

Given the disparate nature of the adverse factors analyzed in association with sex and the overriding influence of female sex on results, our findings suggest an intrinsic biological basis for the improved survival of women with LS-SCLC. Some authors have previously speculated that most sex differences in cancer are attributable to social behaviour rather than to intrinsic sex differences (22). For example, with respect to smoking, clinical intervention studies suggest that women may have more difficulty with smoking cessation than men (23). That said, our results showed that even when a woman smoked during treatment, her expected survival was not surpassed by nonsmoking men. We concur with a number of authors who believe that the failure to collect adequate data on women, and to pay sufficient attention to biological issues, likely form the basis for rationalizing the sex differences in outcomes as being more related to behaviour than biology (24).

Although sex-linked or -influenced biological mechanisms may be critical to an understanding of the sex-based differences in SCLC outcomes, it appears unlikely that a simple underlying model can account for the observed differences between men and women. Data are emerging to suggest that complex multifactorial influences are involved. Maasberg et al (25), investigating the influence of testosterone in SCLC cell lines, have demonstrated high-affinity binding sites for the hormone on the cell lines, and observed that testosterone causes marked growth stimulation in SCLC cell lines which could be counteracted by the addition of antiandrogens. This would suggest an intrinsic 'disadvantage' to maleness when diagnosed with SCLC. In a study by Taggart et al (26), the concentrations of testosterone, dehydroepiandrosterone, androstenedione, lutenizing hormone and sex hormone binding globulin were measured in 38 healthy men and 52 men with primary lung cancer. Compared with healthy men, male lung cancer patients had significantly lower testosterone and dehydroepiandrosterone, higher androstenedione and lutenizing hormone, and no difference in sex hormone binding globulin. These findings suggest that a wide range of abnormalities in androgen metabolism exist in male lung cancer patients rather than a simple reduction in serum testosterone (26).

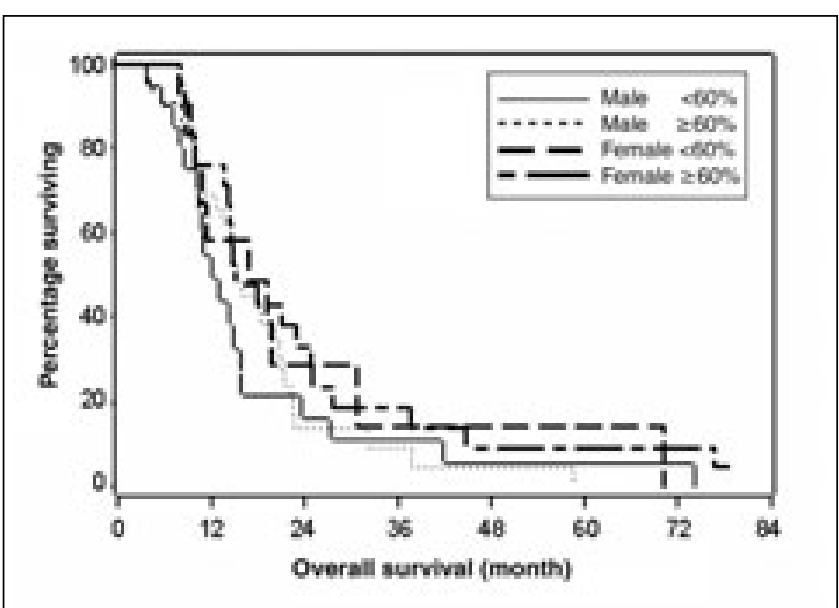

Figure 4) The impact of sex and the diffusion capacity for carbon monoxide $(<60 \% ; \geq 60 \%)$ on overall survival in limited stage small cell lung cancer

Tseng et al (27) have demonstrated a decreased frequency of p53 gene mutations in primary SCLC tumours from women compared with tumours from men, suggesting the presence of distinct and sex-specific biological mechanisms for the development of SCLC. These researchers consider this as one possible mechanism for the improved survival in women. Finally, in another study (28) evaluating the possible role of sex hormones in lung cancer, 52 tumour samples were investigated for their receptor expression using immunohistochemistry. Among these, sex steroid-receptor expression in tumour biopsies was detected most frequently in female patients (in $69 \%$ of 16 women versus $42 \%$ of 36 tumours from men). Future work is being conducted to further analyze these subgroups (28).

The results of the present analysis are tempered by acknowledging the limitations inherent in a retrospective study. Although the total patient cohort studied constituted a substantial dataset, statistical results were limited when subset analyses were performed. Recording of patient variables evolved with practice changes over the time interval studied. Treatment components also changed over the time of analysis, although the evidence presented suggested no impact on outcomes.

\section{CONCLUSIONS}

The survival of women and men with LS-SCLC treated with concurrent ChT/RT can be significantly enhanced by simple measures such as smoking cessation and avoidance of treatment interruptions. Compared with men, women consistently experienced superior survival irrespective of the presence of the adverse treatment variable analyzed. This suggests that the mechanism for improved outcomes in women is likely biologically based and not a result of behavioural differences between sexes. Although the precise mechanism underlying this advantage remains undiscovered, data are emerging to suggest that hormonal interactions may play a pivotal role. In this regard, research into the effect of sex hormones and their modulators in patients with LS-SCLC appears warranted and is currently being explored.

FUNDING: Presented in part at the 22nd Annual Meeting of the European Society for Therapeutic Radiology and Oncology, September 21 to 27, 2003, Copenhagen, Denmark, and at the 45th Annual Meeting of the American Society for Therapeutic Radiology and Oncology, Salt Lake City, Utah, October 19 to 23, 2003. 


\section{REFERENCES}

1. Sherman CA, Rocha Lima CMR, Turrisi AT III. Limited small-cell lung cancer: A potentially curable disease. Oncology (Huntingt) 2000;14:1395-403.

2. Murray N. Small-cell lung cancer at the millennium: Radiotherapy innovations improve survival while new chemotherapy treatments remain unproven. Clin Lung Cancer 2000;1:181-90.

3. Murray N, Coy P, Pater JL, et al. Importance of timing for thoracic irradiation in the combined modality treatment of limited-stage small-cell lung cancer. The National Cancer Institute of Canada Clinical Trials Group. J Clin Oncol 1993;11:336-44.

4. Turrisi AT III, Kyungmann K, Blum R, et al. Twice-daily compared with one-daily thoracic radiotherapy in limited small-cell lung cancer treated concurrently with cisplatin and etoposide. N Engl J Med 1999;340:265-71

5. Takada M, Fukuoka M, Kawahara K, et al. Phase III study of concurrent versus sequential thoracic radiotherapy in combination with cisplatin and etoposide for limited-stage small cell-lung cancer: Results of the Japan Clinical Oncology Group study 9104. J Clin Oncol 2002;20:3054-60.

6. Jeremic B, Shibamato Y, Acimovic L, et al. Initial versus delayed accelerated hyperfractionated radiation therapy and concurrent chemotherapy in limited small-cell lung cancer: A randomized study. J Clin Oncol 1997;15:893-900.

7. Feld R, Sagman U, Leblanc M. Staging and prognostic factors for small cell lung cancer. In: Pass HI, Mitchell JB, Johnson DH, Turrisi AT, Minna JD, eds. Lung Cancer - Principles and Practice. Philadelphia: Lippincott-Raven, 2000:612-27.

8. Videtic GM, Fung K, Tomiak AT, et al. Using treatment interruptions to palliate the toxicity from concurrent chemoradiation for limited small cell lung cancer decreases survival and disease control. Lung Cancer 2001;33:249-58.

9. Videtic GMM, Stitt LW, Dar AR, et al. Continued cigarette smoking by patients receiving concurrent chemoradiotherapy for limited-stage small-cell lung cancer is associated with decreased survival. J Clin Oncol 2003;21:1544-9.

10. Videtic GMM, Stitt LW, Ash RB, et al. Impaired diffusion capacity predicts for decreased treatment tolerance and survival in limited stage small cell lung cancer patients treated with concurrent chemoradiation. Lung Cancer 2004:43:159-66.

11. Johnson BE, Steinberg SM, Phelps R, Edison M, Veach SR, Ihde DC. Female patients with small cell lung cancer live longer than male patients. Am J Med 1988;85:194-6.

12. Wolf M, Holle R, Hans K, Drings P, Havemann K. Analysis of prognostic factors in 766 patients with small cell lung cancer (SCLC): The role of sex as a predictor for survival. Br J Cancer 1991;63:986-92.

13. de Wet M, Falkson G, Rapoport BL. Small cell lung cancer: Analysis of factors influencing the response to treatment and survival. Oncology 1994;51:523-34.
14. Christodolou C, Pavlidis N, Samantas E, et al. Prognostic factors in Greek patients with small cell lung cancer (SCLC). A Hellenic Cooperative Oncology Group study. Anticancer Res 2002;22:3749-57.

15. Spiegelman D, Maurer LH, Ware JH, et al. Prognostic factors in small-cell carcinoma of the lung: An analysis of 1521 patients. J Clin Oncol 1989;7:344-54

16. Albain KS, Crowley JJ, LeBlanc M, Livingston RB. Determinants of improved outcome in small-cell lung cancer: An analysis of the 2580-patient Southwest Oncology Group data base. J Clin Oncol $1990 ; 8: 1563-74$

17. Mennecier B, Lebitasy MP, Moreau L, et al. Women and small cell lung cancer: Social characteristics, medical history, management and survival: A retrospective study of all the male and female cases diagnosed in Bas-Rhin (Eastern France) between 1981 and 1994. Lung Cancer 2003;42:141-52.

18. Murray N, Hadzic E, Shah A, et al. Alternating chemotherapy and thoracic irradiation with concurrent cisplatin-etoposide for limited stage SCLC. Proc Am Soc Clin Oncol 1984;3:321a.

19. Martinez FJ, Paine R III. Medical evaluation of the patient with potentially resectable lung cancer. In: Pass HI, Mitchell JB, Johnson DH, Turrisi AT, eds. Lung Cancer - Principles and Practice. Philadelphia: Lippincott-Raven, 1996:511-36.

20. Turrisi AT III, Withers HR III. Radiotherapy in limited small cell lung cancer: Fractionation and timing of modalities. Semin Radiat Oncol 1995;5:50-56.

21. Videtic GM, Truong PT, Dar AR, Yu EW, Stitt LW. Shifting from hypofractionated to "conventionally" fractionated thoracic radiotherapy: A single institution's 10-year experience in the management of limited-stage small-cell lung cancer using concurrent chemoradiation. Int J Radiat Oncol Biol Phys 2003;57:709-16.

22. McCann J. Gender differences in cancer that don't make sense or do they? J Natl Cancer Inst 2000;92:1560-2.

23. Commentary: Women and Smoking: A report of the Surgeon General. Oncology (Huntingt) 2003;17:453

24. Payne S. 'Smoke like a man, die like a man?': A review of the relationship between gender, sex and lung cancer. Soc Sci Med 2001;53:1067-80.

25. Maasberg M, Rotsch M, Jaques G, Enderle-Schmidt U, Weehle R, Havemann K. Androgen receptors, androgen-dependent proliferation, and 5 alpha-reductase activity of small-cell lung cancer cell lines. Int J Cancer 1989;43:685-91.

26. Taggart DP, Gray CE, Bowman A, Faichney A, Davidson KG. Serum androgens and gonadotrophins in bronchial carcinoma. Respir Med 1993;87:455-60.

27. Tseng JE, Rodriguez M, Ro J, Liu D, Hong WK, Mao L. Gender differences in $\mathrm{p} 53$ mutational status in small cell lung cancer. Cancer Res 1999;59:5666-70.

28. Kaiser U, Hofmann J, Schilli M, et al. Steroid-hormone receptors in cell lines and tumor biopsies of human lung cancer. Int J Cancer 1996;67:357-64 


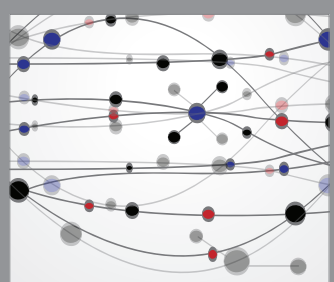

The Scientific World Journal
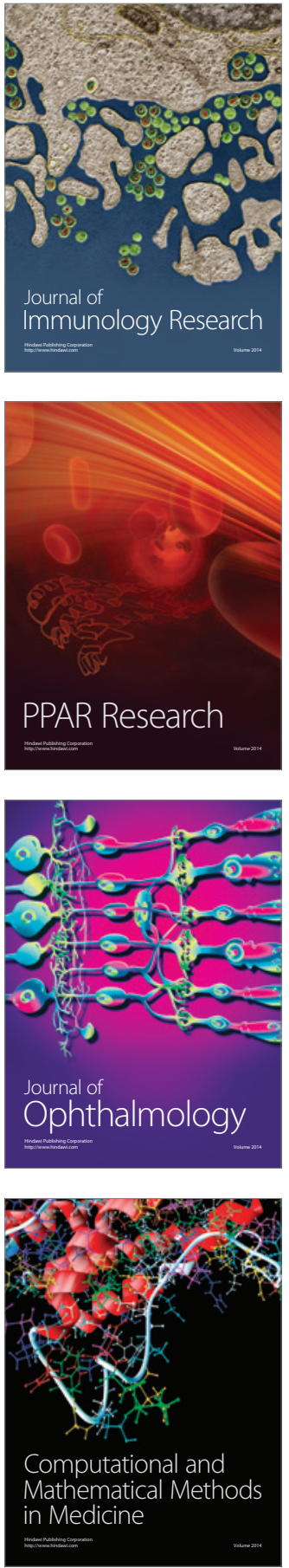

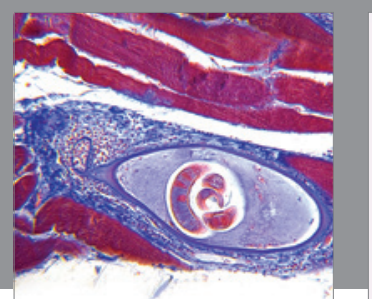

Gastroenterology Research and Practice

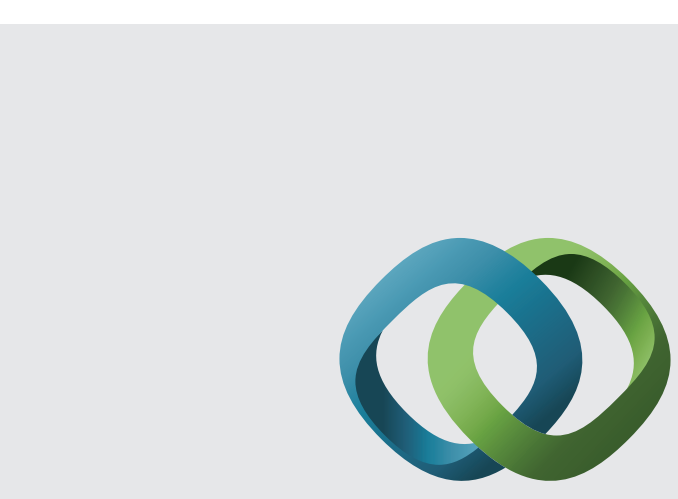

\section{Hindawi}

Submit your manuscripts at

http://www.hindawi.com
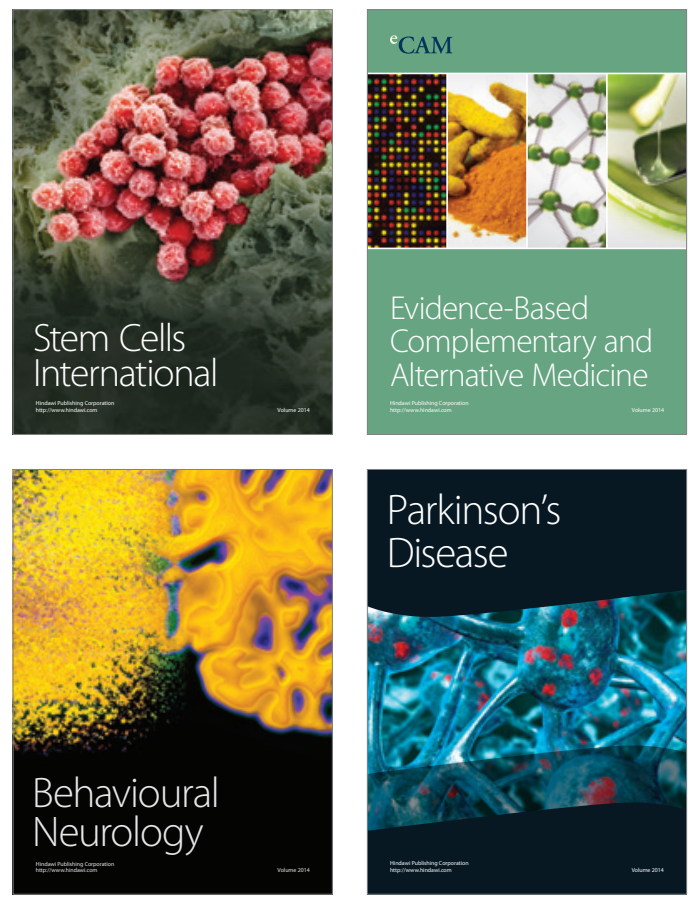
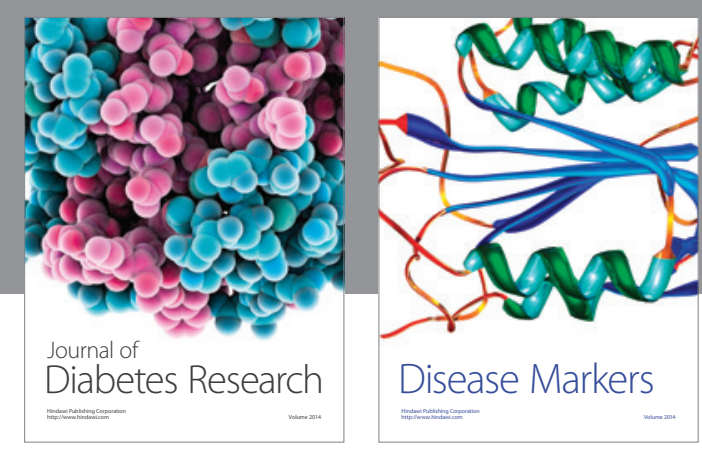

Disease Markers
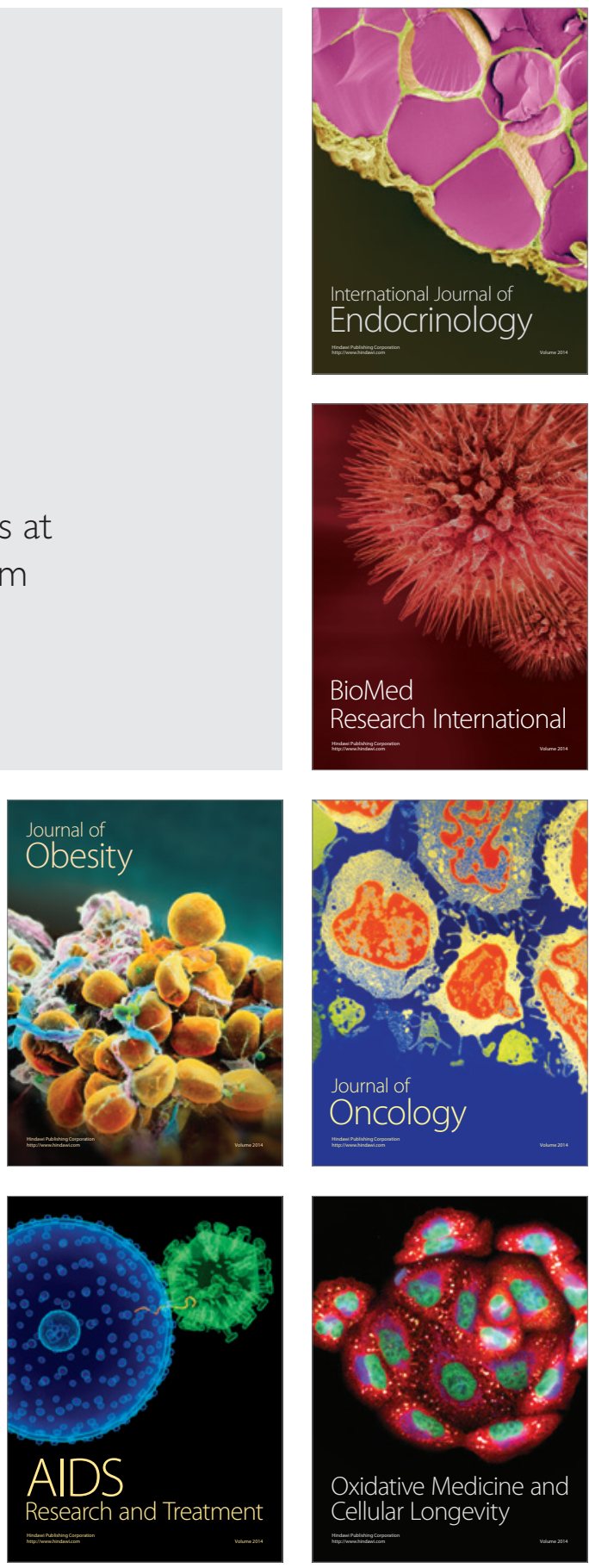